TOMÁŠ COUFAL, Ph.D.

E-mail: tomas.coufal@usi.vutbr.cz MAREK SEMELA, Ph.D.

E-mail: marek.semela@usi.vutbr.cz

Brno University of Technology,

Institute of Forensic Engineering

Purkyňova 464/118, 61200 Brno, Czech Republic
Safety and Security in Traffic

Review

Submitted: Oct. 8, 2014

Approved: Feb. 2, 2016

\title{
DETERMINATION OF SELECTED CRASH PARAMETERS IN HEAD-ON VEHICLE COLLISION WITH ROLLOVER
}

\begin{abstract}
The paper presents complete results of the head-on small overlap crash test of vehicle with driver moving at a speed of approximately $12 \mathrm{~m} / \mathrm{s}$ against stationary vehicle with post-crash rollover. When a crash does not involve the main crush-zone structures, the occupant compartment is not well protected. The emphasis in the paper was put on determination and presentation of crash parameters for the application in traffic accident analyses and for simulation with the help of software for accident reconstruction. The experimentally measured data from the crash test were analysed and important crash parameters which are necessary for accident reconstruction were obtained. The crash test was specific because of rollover of the impacting vehicle resulting from small overlap. The results have shown that small overlap accident is extremely dangerous for the crew with the possibility of vehicle rollover and occupant head and neck injury. Also in this case, at relative low speed, the driver suffered light neck and head injury in the following days and the longitudinal damage was relatively large. The input parameters for accident reconstruction software as the result of performed crash test were gained.
\end{abstract}

\section{KEY WORDS}

crash test; impact; vehicle; traffic accident; forensic engineering; rollover; small overlap;

\section{INTRODUCTION AND GOAL OF THE RESEARCH}

The technical assessment of the cause of a traffic accident usually involves a complex analysis of the accident progress, which usually involves a study of the actual collision of the vehicles. Although experts use sophisticated simulation programs to analyse the accident progress, the correctness of the result greatly depends on the parameters input by the expert, which must move within a technically acceptable range. To apply crash parameters within a technically acceptable range during analyses of traffic accidents, it is necessary to draw data from real crash tests on the basis of which it is possible to analyse the input parameters necessary for the actual study of the crash. Issues connected with the technical reconstruction of traffic accidents leading to determination of the cause of the accident have been tackled by many authors, e.g. [2, 3, 7, 8]. Issues connected with the desired collision parameters as regards the force and the related size of the impulse, the energy intensity of the collision, rigidity and the restitution coefficient, are intensively studied by [1, 4, 5, 6, 911,12 and 13]. In the overwhelming majority of cases, the data from crash tests performed in Europe are strictly protected and are not available for the needs of experts who perform reconstructions especially for forensic purposes. As result, a frontal small overlap crash test was performed with the active participation of the Institute of Forensic Engineering (IFE), Brno University of Technology. The research [14] emphasises the fact that in crashes with a small overlap (less than 30\%), the risk of serious injury sharply rises especially because of the misalignment of structures that absorb energy, such as longitudinal girders. This type of collision can cause mutual contact of the wheels and serious movement of the damaged parts into the cabin. The authors documented this fact in an analysis of twenty accidents of this type, where they studied the effect of the impact velocity, the impact angle, the width of the overlap, etc. The publication [15] also points out the issues connected with frontal small overlap collisions in relation to the occupants, specifically by tests from a speed of $17.7 \mathrm{~m} / \mathrm{s}$ in various impact configurations with primary action of the force against the wheels, shock absorbers and the B-pillar. It is clear from the content that it causes great damage and penetration of deformations into the cabin. In addition, the impact causes the dummy and the steering wheel to move mutually crosswise, thus reducing the interaction between the frontal airbag and the dummy in most cases. Based on these tests, the Institute for Highway Safety (IIHS) [16] started executing 
Small Overlap Crash Tests at a speed of $17.8 \mathrm{~m} / \mathrm{s}$ with a $25 \%$ crosswise overlap of the front part of the vehicle against a solid barrier whose impact corner is rounded with a 0.150 m diameter. The National Highway Traffic Safety Administration (NHTSA) [17] has developed two moveable deformable barriers for small overlap crashes to allow repeatability of the tests. The work [18] introduces the performed, completely repeatable, tests on these barriers. The work [19] also sums up the insufficient emphasis placed by the car makers on small overlap crashes, which are very critical due to their consequences for the occupants. Within their work, the authors performed a small overlap crash test of very different cars, following from the collected real accidents, and discussed the reconstructions of these collisions. In certain cases, the given crash configuration causes one vehicle to roll up the other vehicle's tyre and roll over, i.e. a combination of two very serious factors. The research [20] summarizes issues connected with rollover related to the rotational velocity, the input velocities, and deceleration during the rollover, roof deformation, the overall damage, the motion period and the residual space for the driver's head. The data were compared and processed in detail also with a view to repeatable tests performed by the NHTSA on a Subaru car. The analyses also show comparison of the acceleration peaks and the impact periods. The rollovers, simulations of initialization and progress of these tests, especially with large SUV cars, have long been studied by a team from the University of Virginia [21], which has developed a rollover initiation test system (RITS), mainly for the simulation of initiating conditions for the rollover and simulation of contact conditions of the body with the road during the rollover. The authors of this work personally visited the workplace in 2012. Important factors of input parameters for the reconstruction of this type of traffic accident include parameters of the deformation, the restitution coefficient, the amount of deformation energy and the post-impact velocities, i.e. $\Delta \mathrm{V}$, which means the differences in velocities during the impact phase, which can indicate the consequences of the accident for the occupants. Changes in velocities during collisions have been tackled by many works; for example, the authors of this research [22] studied 84 rear collisions with twenty vehicles, or research [23], which warned about a great amount of chest injuries in the case of small overlap frontal crashes. The modelling involved a Hybrid III dummy and concentrated on studying the acting force and velocity change in relation to potential rib injury. Regarding occupant injury, the mentioned tests are tackled e.g. by this publication [24]. The mentioned arguments prompted the authors of this work to concentrate on real small overlap crash tests as well. By virtue of this research, the experts will be able to work with input data that clarify the solution of the accident progress as close to the real occurrence as possible when solving a comparable traffic accident. The goal of the research is thus a detailed analysis of a particular real specific small overlap crash test with regard to the input and control values.

\section{DESCRIPTION OF PERFORMED CRASH TEST}

The vehicles subjected to the crash test included a Fiat Marea Weekend and Mitsubishi Carisma. The basic parameters are listed in Table 1.

A Fiat Marea Weekend, moving at a speed of approx. $43 \mathrm{~km} / \mathrm{h}$ (ca. $12 \mathrm{~m} / \mathrm{s}$ ), frontally crashed with its right side, with an approximately $15 \%$ overlap, into a stationary Mitsubishi Carisma, see Figure 1. Because of the small overlap crash, the Fiat Marea Weekend rolled over as a result of the mutual contact of the cars' right wheels. The Fiat Marea was driven by a driver on dry tarmac and the rollover was not planned during configuration of the crash test. The top camera was not set, top images during post-crash phase were made by a drone.

During the crash test, both cars were fitted with data measuring equipment. The Fiat Marea Weekend carried a PicDAQ machine made by DSD Linz, Austria. The PicDAQ machine is equipped with a three-axis accelerometer and gyroscope. Signals from the sensors were recorded with a maximum possible frequency of $1 \mathrm{kHz}$. The Mitsubishi Carisma carried a complex autonomous C DAQ USI measuring machine, which was developed at IFE of the Brno University of Technology. The measuring equipment was connected to a three-axis accelerometer and gyroscope whose signal was recorded with a $10 \mathrm{kHz}$ frequency. To use the measured

Table 1 - Vehicle Parameters

\begin{tabular}{||c|c|c||}
\hline \multirow{2}{*}{ Parameter } & \multicolumn{2}{|c||}{ Vehicle } \\
\cline { 2 - 3 } & Fiat Marea Weekend & Mitsubishi Carisma \\
\hline \hline Engine & $1.9 \mathrm{JTD}$ - Diesel & $1.8 \mathrm{GDI}$ - Gasoline \\
\hline Body style & Combi & 2001 \\
\hline Model year & 1999 & $1,510 \mathrm{~kg}$ \\
\hline Total weight & $1,430 \mathrm{~kg}$ & Manual/5 gears \\
\hline Transmission & Manual/5 gears & Front Wheel Drive \\
\hline Final drive & Front Wheel Drive & \\
\hline
\end{tabular}




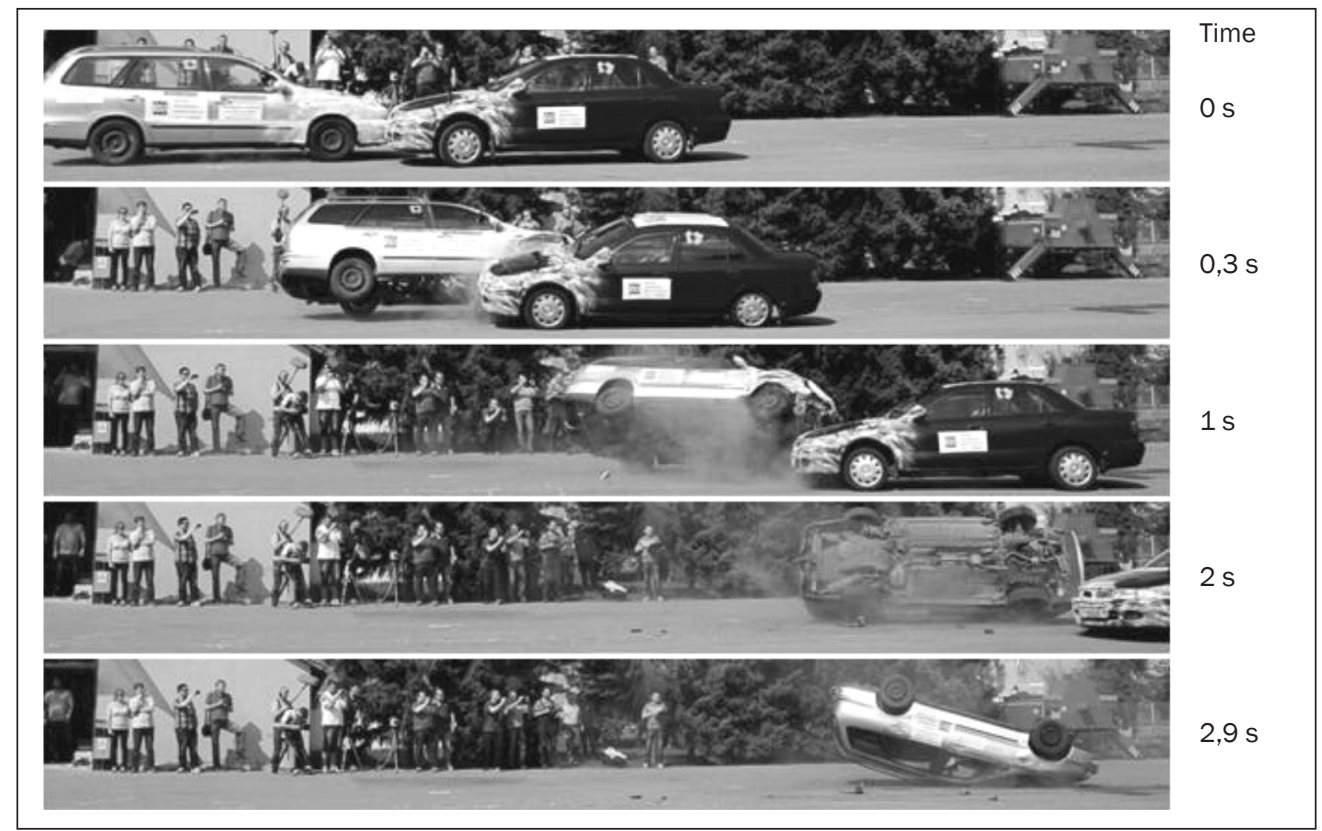

Figure 1 - Sequence of the vehicles' crash from a video recording

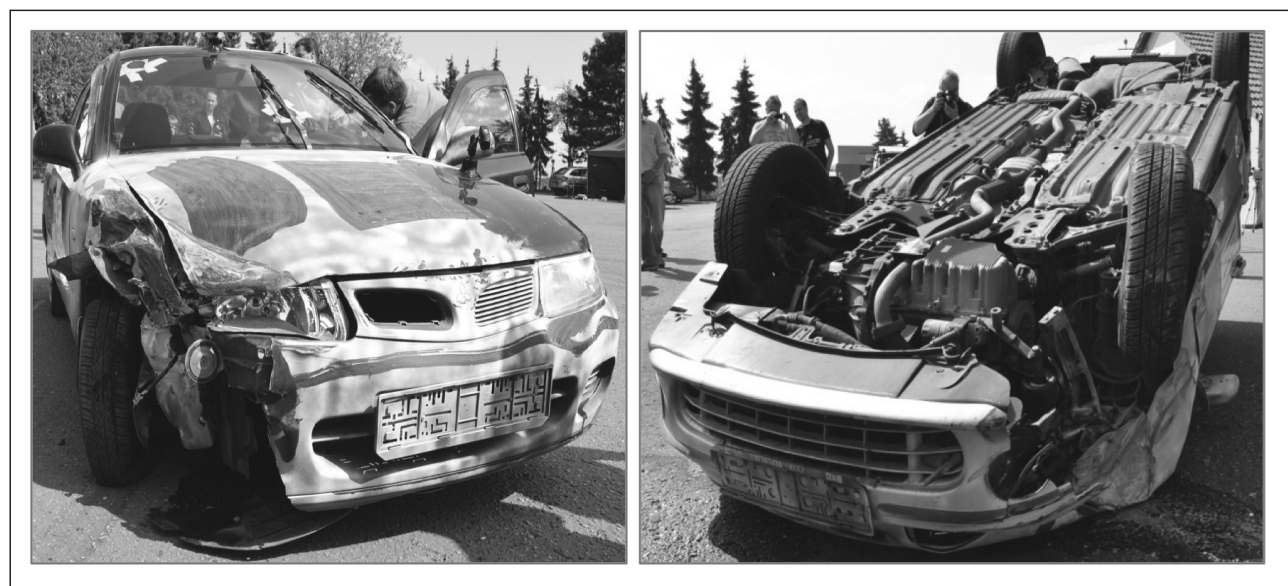

Figure 2 - Damage of stationary vehicle Mitsubishi (left) and moving vehicle Fiat (right)

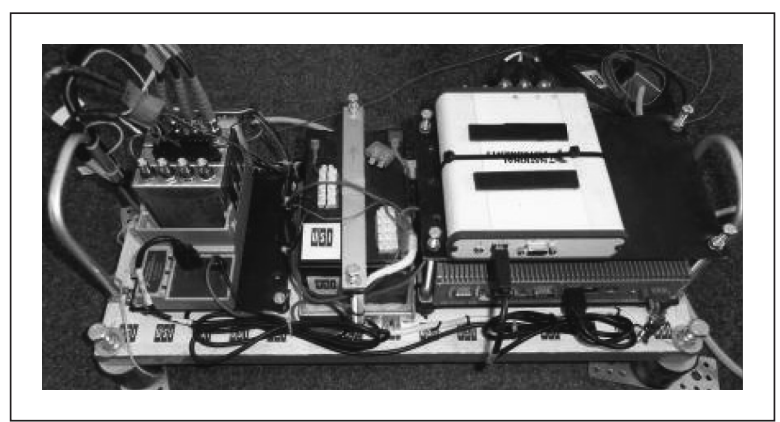

Figure 3 - Data collection equipment C-DAQ

data from the crash test, it is necessary to define the vehicles' coordinate system. The acceleration sensors and the yaw rate sensors were thus located in the individual vehicles in agreement with the coordinate system specified by the standard SAE J1733 [10].

\section{ANALYSIS OF DATA MEASURED IN THE CRASH TEST}

Data measured in the crash test were further processed to acquire the impact and post-impact parameters of the vehicles. The signal from the accelerometer was filtered by a CFC (Channel Frequency Class) filter, which is designed for application in crash tests pursuant to the Crash Analysis Criteria Description [9]. For filtering of the recording from the accelerometers located in the vehicle, a CFC 60 filter pursuant to the standard SAE J211 (Vehicle Instrumentation for Impact Test) was used. The speed progress over time was calculated by integration of the acceleration over time (Formula 1). Then the path progress over time was calculated by a second integration of acceleration over time (Formula 2). The output signal from the 
gyroscope, which showed the immediate value of angular velocity, was integrated over time (Formula 3) to obtain the progress of the angular velocity over time. Based on Newton's second law (Formula 4), we calculated the force in the progress of the impact and used it to calculate the force impulse (Formula 5). The overall energy balance during the impact can be calculated by integration of the force over the depth of the deformation (Formula 6).

$$
\begin{aligned}
& \vec{v}(t)=\int_{t_{1}}^{t_{2}} \vec{a}(t) d t \\
& \vec{s}(t)=\int_{t_{1}}^{t_{2}} \int_{t_{1}}^{t_{2}} \vec{a}(t) d t d t \\
& \varphi(t)=\int_{t_{1}}^{t_{2}} \vec{\omega}(t) d t \\
& \vec{F}=m \cdot \vec{a} \\
& \vec{I}=\int_{t_{1}}^{t_{2}} \overrightarrow{F_{(t)}} d t \\
& E_{(t)}=\int_{s_{1}}^{s_{2}} \overrightarrow{F_{(t)}} d s \\
& e=\sqrt{\frac{E_{D E}}{E_{D}}}
\end{aligned}
$$

where:

$a_{(t)}\left[\mathrm{m} / \mathrm{s}^{2}\right]$ - Acceleration,

e [-] - Coefficient of restitution,

$E_{(t)}[\mathrm{J}] \quad-$ Energy,

$E_{D}[\mathrm{~J}]$ - Deformation energy corresponding to plastic - permanent deformation of the vehicles,

$E_{D E}[\mathrm{~J}] \quad$ - Elastic part of the energy correspo din to elastic deformation of the vehicles,

$F_{(t)}[\mathrm{N}] \quad$ - Impact force,

$I_{(t)}[N . s] \quad-$ Impulse,

$m[\mathrm{~kg}] \quad$ - Weight of the vehicle,

$\mathrm{s}_{(\mathrm{t})}[\mathrm{m}] \quad$ - Distance,

$t[\mathrm{~s}] \quad$ - Time,

$v_{(t)}[\mathrm{m} / \mathrm{s}] \quad-$ Speed,

$\varphi_{(t)}\left[^{\circ}\right] \quad$ - Angular distance,

$\omega_{(t)}[\% / s] \quad$ - Angular velocity.

Figure 4 shows a graphic illustration of all the significant parameters of the impact and the post-impact motion of the Fiat Marea Weekend. Figure 5 shows the progress of acceleration, velocity and path during the impact, which lasted for 0.276 s. Figure 6 shows an illustration of velocity change during the impact from $12 \mathrm{~m} / \mathrm{s}$ to $4.6 \mathrm{~m} / \mathrm{s}$, then the progress of the path and velocity up to the final position of the vehicle, which is located at $2.9 \mathrm{~s}$ and $9.6 \mathrm{~m}$ behind the crash point.

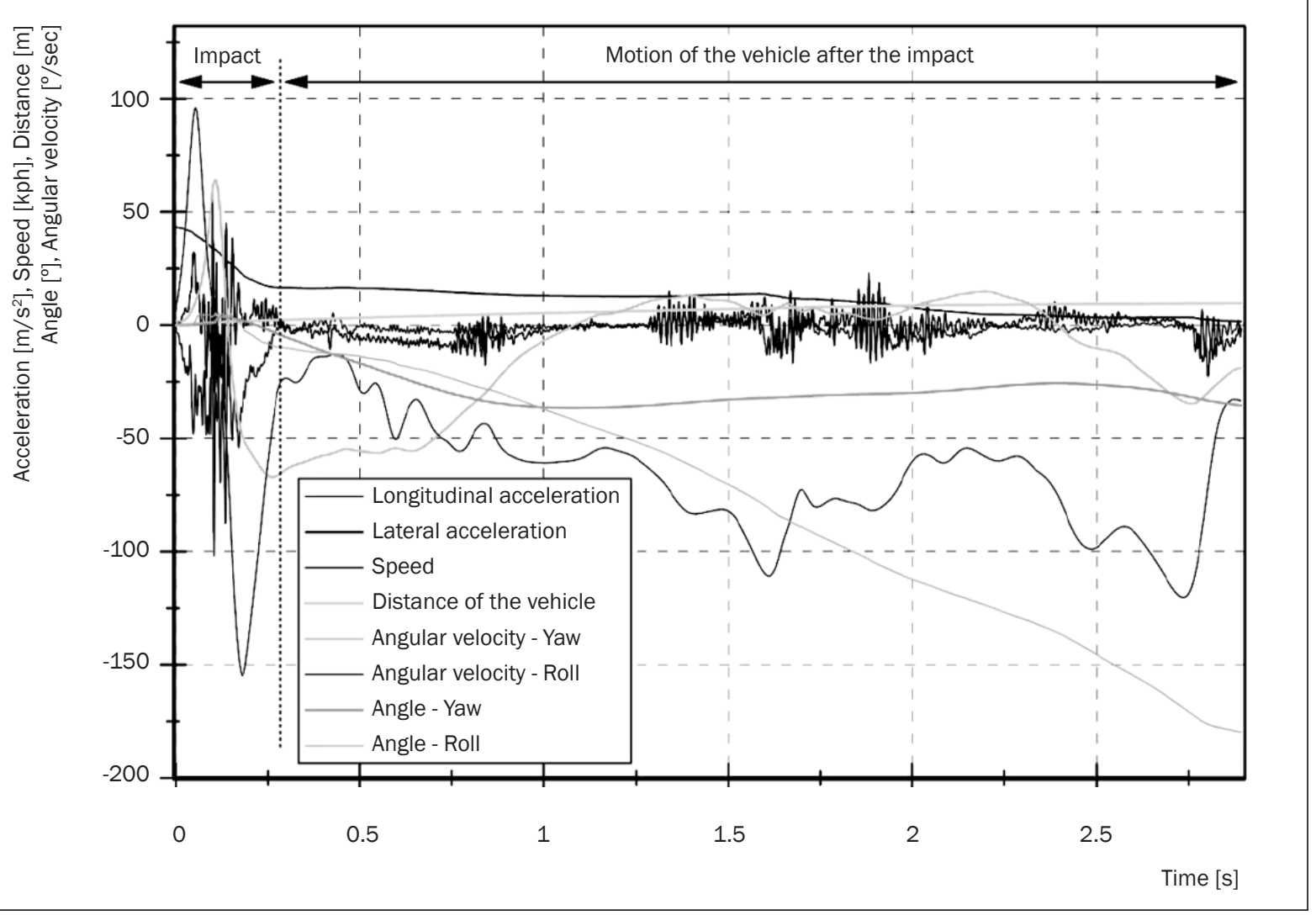

Figure 4 - Parameters of motion of Fiat Marea Weekend 


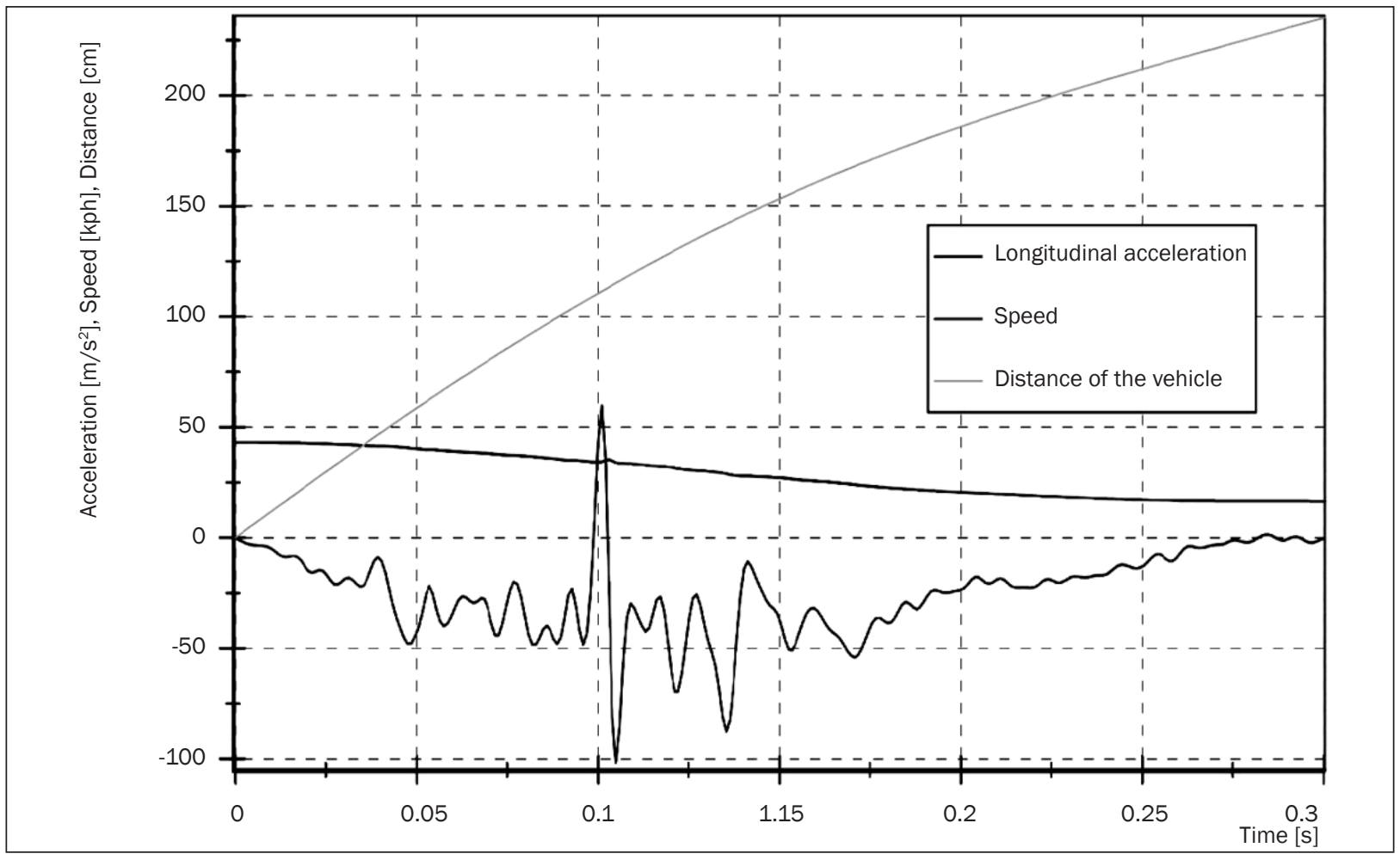

Figure 5 - Acceleration, Speed and Distance of Fiat Marea during the impact

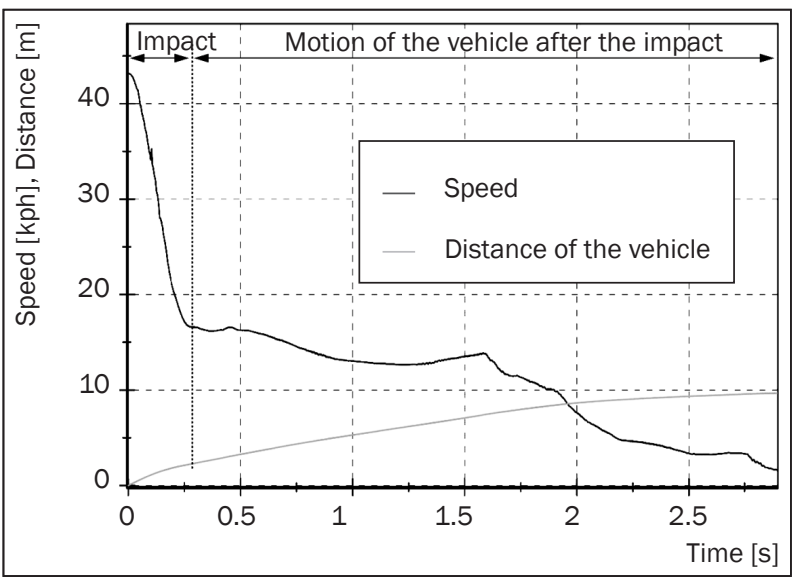

Figure 6 - Speed and Distance of Fiat Marea Weekend

Figure 7 shows the angular velocity and angular path round the longitudinal axis of the vehicle - Roll and round the vertical axis. Rotation about the longitudinal axis caused the vehicle to roll over by $180^{\circ}$ onto the roof.

Figure 8 shows a graphic illustration of all the significant parameters of the impact and the post-impact motion of the Mitsubishi Carisma. Figure 9 shows the progress of acceleration, velocity and path during the impact, which lasted for $0.276 \mathrm{~s}$. Figure 10 shows an illustration of the velocity change during the impact from 0 to $6.7 \mathrm{~m} / \mathrm{s}$, then the course of the path and velocity up to the final position of the vehicle, which is located at $3.2 \mathrm{~s}$ and $9.4 \mathrm{~m}$ behind the crash point.
Figure 11 shows the angular velocity and angular path round the vertical axis of the vehicle - Yaw. Unlike the previous vehicle, the rotation about the longitudinal axis is not significant, because the car did not roll over onto its roof. The vehicle's rotation about the vertical axis results in initial locking of the vehicles, with almost minimum clockwise rotation towards the collision and then, approximately in the half-period of the actual collision, to anti-clockwise rotation outwards from the collision. In the progress of the post-impact motion, the vehicle slightly yaws in a clockwise rotation to the final position.

Figure 12 shows a graphic illustration of the progress of acceleration, velocity and difference in the covered paths of the individual vehicles during the impact. The difference in the vehicles' paths determines the vehicles' overlap during the impact, or more precisely, the overall depth of the deformation. To make it more illustrative, the sign convention in the Mitsubishi Carisma was reversed. Figure 12 documents the boundary between the compression and restitution phases of the impact, which is characterised by the maximum depth of deformation, and equalizing of both vehicles' speeds during the impact (crossing of the cars' velocity courses). In the restitution phase, the vehicles bounce, thus reducing the deformation depth and changing the velocities. Figure 13 shows an illustration of the impact force progress during the vehicles' impact, with the compression and restitution phase marked. Figure 14 shows an illustration of the energy balance during the impact with the energy 


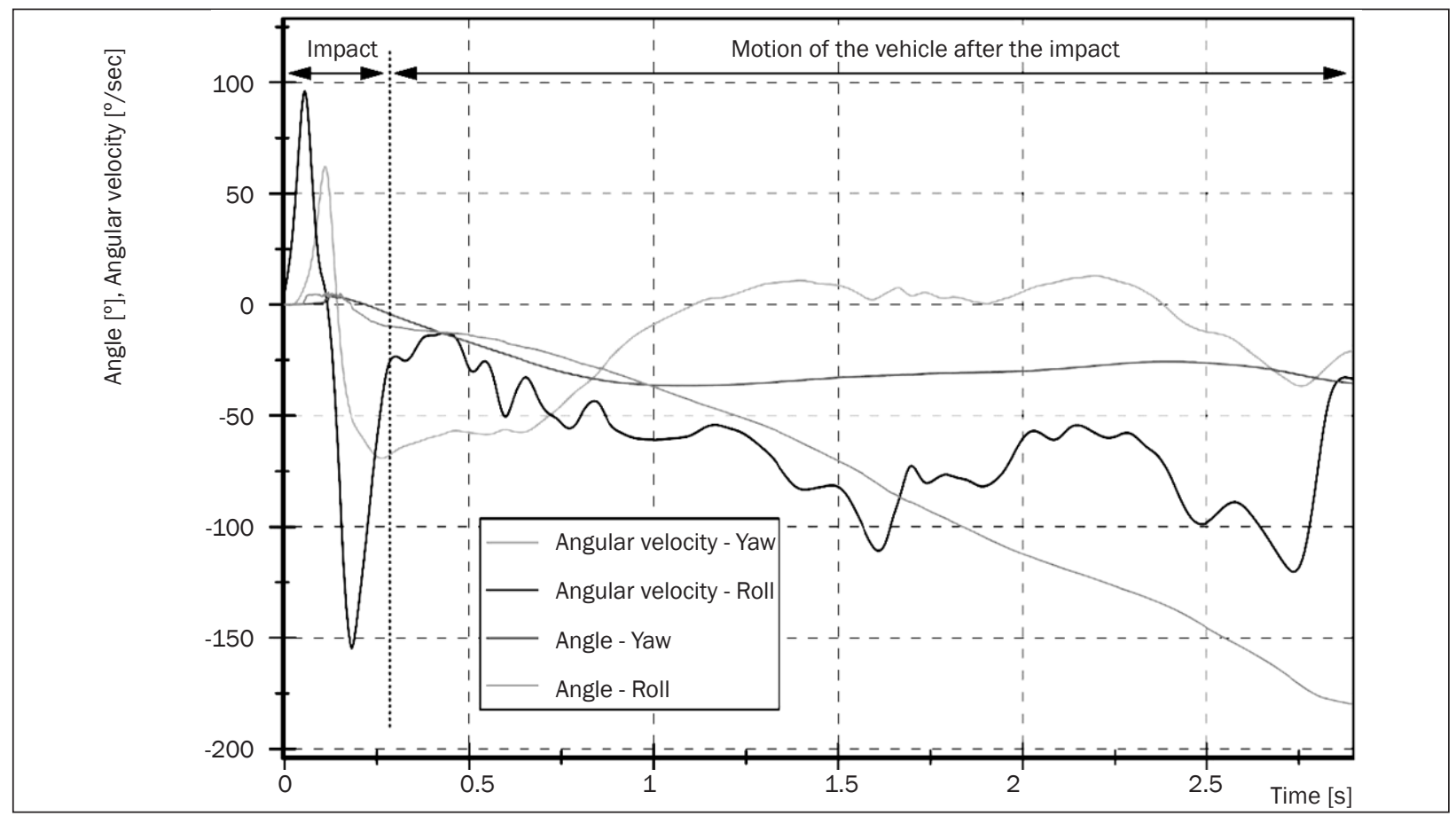

Figure 7 - Angular velocity and Angle of Fiat Marea Weekend

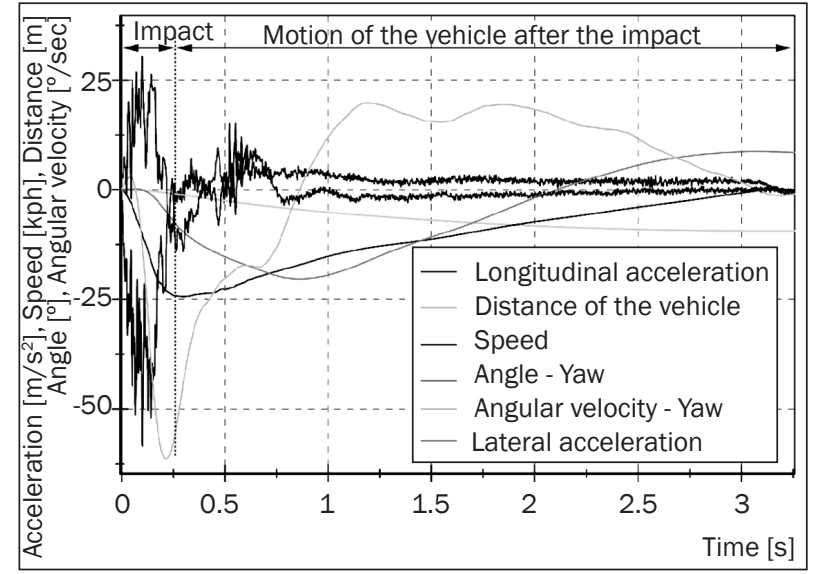

Figure 8 - Parameters of motion of Mitsubishi Carisma

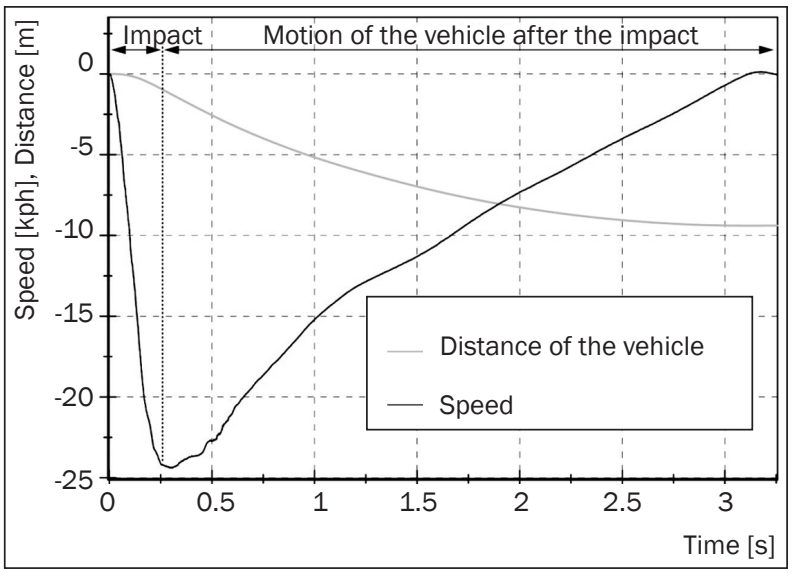

Figure 10 - Speed and distance of Mitsubishi Carisma

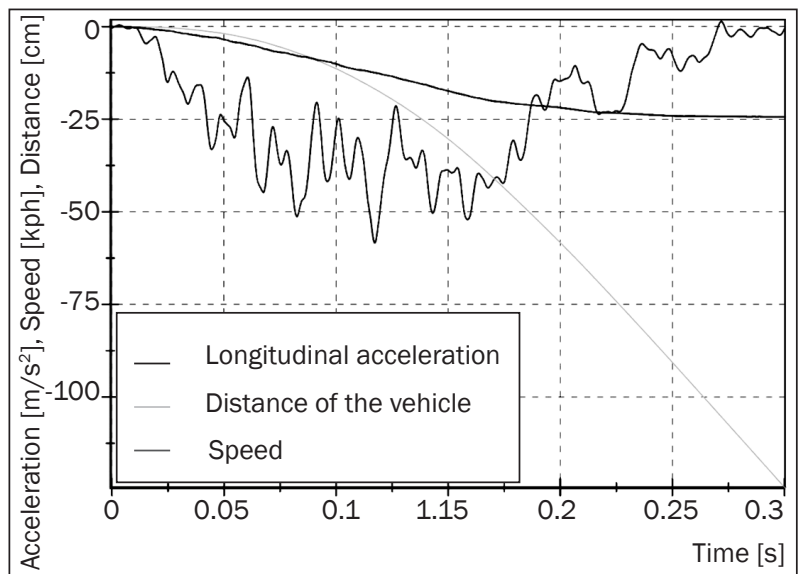

Figure 9 - Acceleration, Speed and Distance of Mitsubishi Carisma during the impact

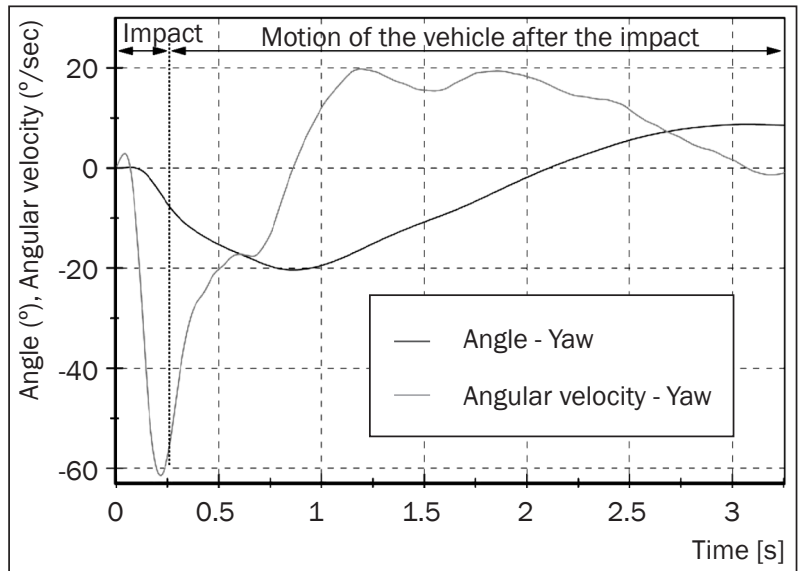

Figure 11 - Angular velocity and Angle of Mitsubishi Carisma 


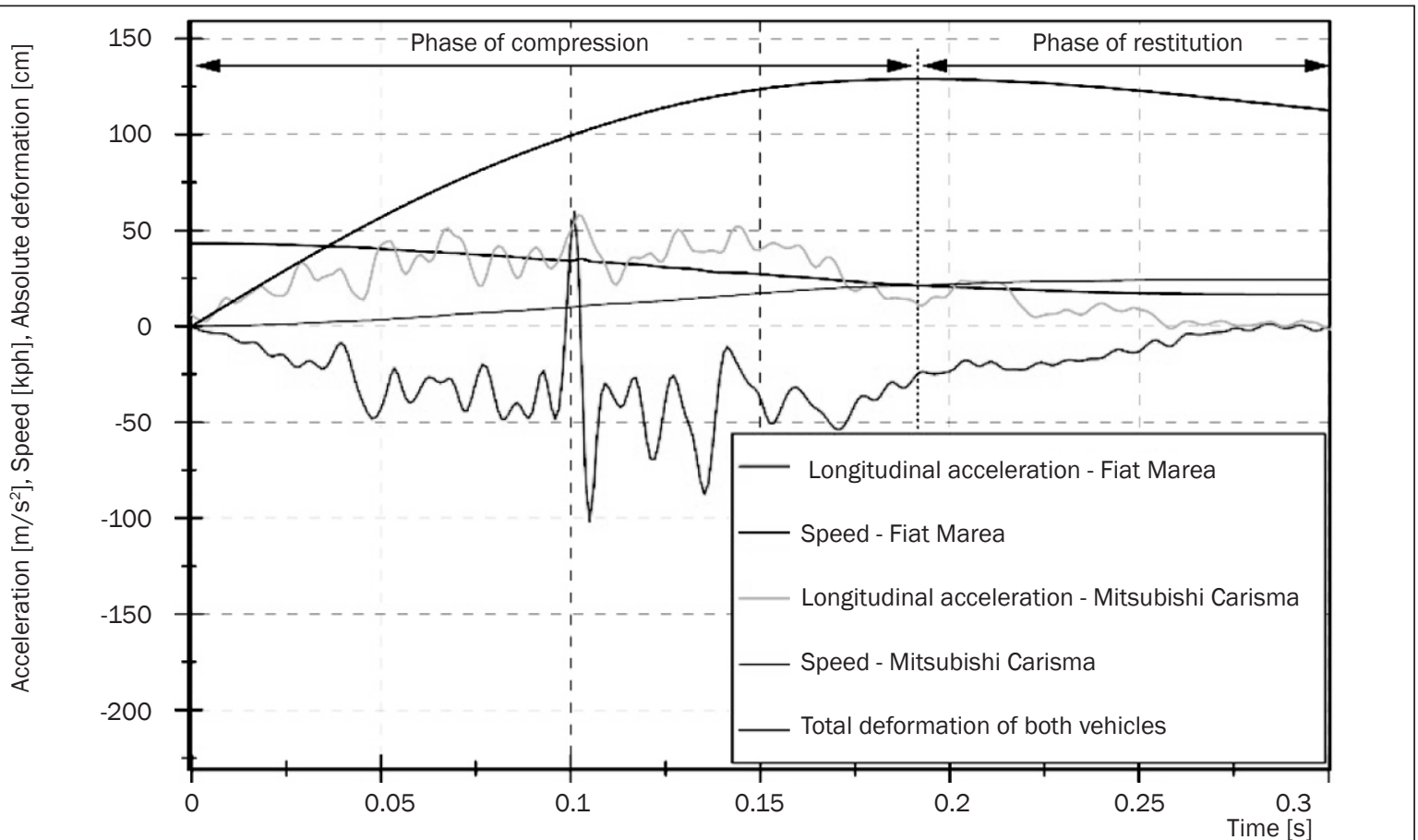

Figure 12 - Acceleration, speed and total deformation of both vehicles

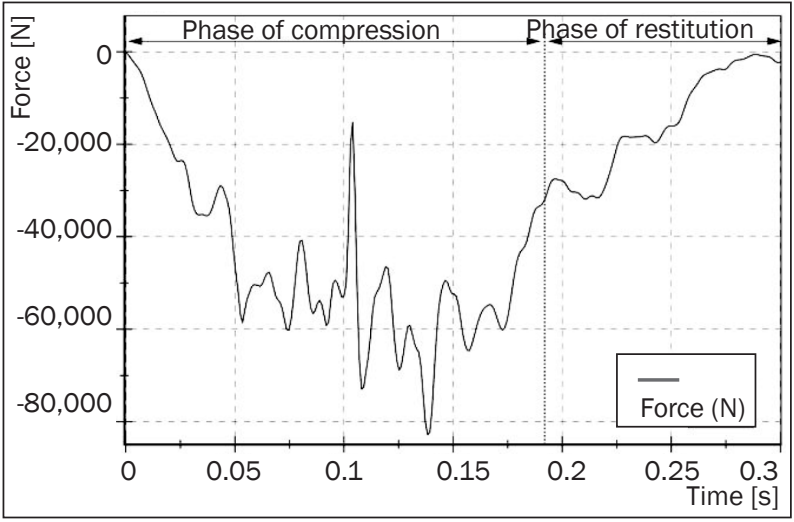

Figure 13 - Force during the impact

cumulated in the elastic part of the deformation marked, which moves back by the action of restitution, and with the deformation energy marked, which represents the action of the impact force within the path - the depth of plastic (permanent) deformation.

Table 2 summarizes all the significant parameters of the impact and post-impact motion of the vehicles to their final positions.

The mentioned impact parameters were evaluated from a real impact test, thus they can be suitably applied as input and control parameters in analyses of comparable traffic accidents within forensic engineering. The overall experimental analysis of the impact test and the subsequent reverse analysis of the accident progress in the simulation program will assist forensic experts in analysing traffic accidents.

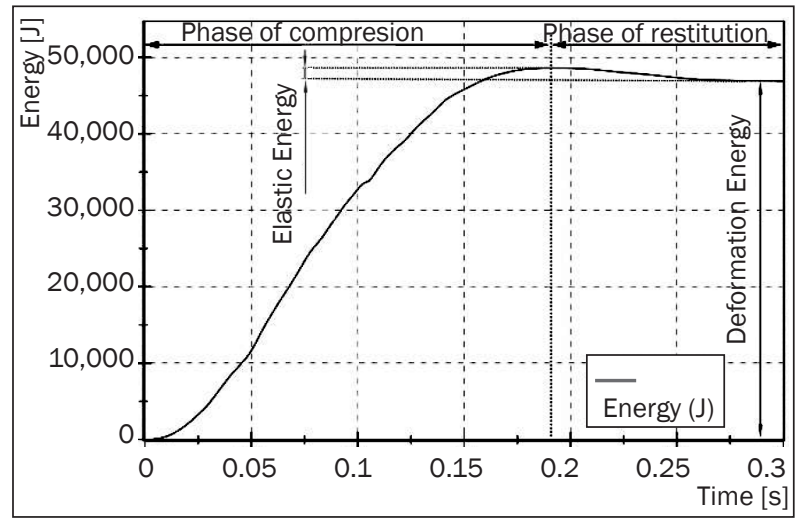

Figure 14 - Energy during the impact

\section{MODELLING OF THE IMPACT}

The experimentally measured data from a real crash test were further used in the modelling of the impact assisted by a simulation program. The impact modelling proceeded in simulation programs allows modelling of the impact and post-impact motion with gradual optimization of the input data. The impact modelling proceeds by using the forward method, i.e. from the impact to the final positions. The program uses the so-called impulse-momentum model, which supplies all contact forces acting in the deformed section of the damaged part of the vehicle with a single force resultant, which passes through the so-called impact point.

It thus represents a significant simplification compared with the real situation. Regarding the time action of the force, this is an impulse whose size corresponds 
Table 2 - Parameters of the impact and post-impact motion

\begin{tabular}{|c|c|c|}
\hline \multirow{2}{*}{ Parameters } & \multicolumn{2}{|c|}{ Vehicle } \\
\hline & Fiat Marea & Mitsubishi Carisma \\
\hline \multirow{3}{*}{ Start impact (time, speed, distance) } & $t=0 \mathrm{~s}$ & $\mathrm{t}=0 \mathrm{~s}$ \\
\hline & $\mathrm{v}=12 \mathrm{~m} / \mathrm{s}$ & $\mathrm{v}=0 \mathrm{~m} / \mathrm{s}$ \\
\hline & $\mathrm{s}=0 \mathrm{~m}$ & $\mathrm{~s}=0 \mathrm{~m}$ \\
\hline \multirow{3}{*}{$\begin{array}{l}\text { End of the compression } \\
\text { phase (maximal deformation) }\end{array}$} & $t=0.193 \mathrm{~s}$ & $t=0.193 \mathrm{~s}$ \\
\hline & $v=5.9 \mathrm{~m} / \mathrm{s}$ & $v=5.9 \mathrm{~m} / \mathrm{s}$ \\
\hline & $\mathrm{s}=1.81 \mathrm{~m}$ & $\mathrm{~s}=0.53 \mathrm{~m}$ \\
\hline \multirow{3}{*}{ Finish impact - end of the restitution phase } & $\mathrm{t}=0.276 \mathrm{~s}$ & $\mathrm{t}=0.276 \mathrm{~s}$ \\
\hline & $v=4.6 \mathrm{~m} / \mathrm{s}$ & $v=6.75 \mathrm{~m} / \mathrm{s}$ \\
\hline & $\mathrm{s}=2.24 \mathrm{~m}$ & $\mathrm{~s}=1.06 \mathrm{~m}$ \\
\hline Delta V (between pre and post-impact) & $\Delta \mathrm{v}=7.4 \mathrm{~m} / \mathrm{s}$ & $\Delta v=6.75 \mathrm{~m} / \mathrm{s}$ \\
\hline \multirow{3}{*}{ Final position of the vehicles } & $t=2.89 \mathrm{~s}$ & $t=3.17 \mathrm{~s}$ \\
\hline & $\mathrm{v}=0 \mathrm{~m} / \mathrm{s}$ & $\mathrm{v}=0 \mathrm{~m} / \mathrm{s}$ \\
\hline & $\mathrm{s}=9.63 \mathrm{~m}$ & $\mathrm{~s}=9.39 \mathrm{~m}$ \\
\hline Impulse & \multicolumn{2}{|c|}{$I=8,700$ N.s } \\
\hline Coefficient of restitution & \multicolumn{2}{|c|}{$e=0.16$} \\
\hline Total deformation energy & \multicolumn{2}{|c|}{$E_{D}=47,000 \mathrm{~J}$} \\
\hline
\end{tabular}

to the control value in solving the impact. The size of the impulse is determined by the restitution coefficient and its direction is determined by the impact plane in which a potential skid is realized. In terms of direction, the impulse moves in the area of the so-called friction cone, [25]. Other significant control values include the impact point velocity (the size of the velocity describes whether the impact is with a skid or without a skid), the vehicles' velocity changes during the collision, i.e. $\Delta \mathrm{V}$, and the amount of deformation energy. The equivalent energy speeds (EES) of both vehicles are calculated from the deformation energy value, based on the position of the impact point from the contours of both vehicles at the moment of maximum deformation depth in the direction of the impulse.

At least the following parameters should be observed in the modelling:

- The dimensions and weights of the vehicles, the position of the vehicles' centres of gravity against the selected impact point position;

- Impact positions of the vehicles and turning;

- Impact and post-impact velocities and paths, which the vehicles have reached from the impact to the final position;

- Size of the overall deformation energy;

- Overall corresponding character of the vehicles' movement.

At the start of the modelling, it is necessary to create a system of essential values for the particular studied case. In case of a performed crash test, it is necessary to monitor the position of the impact point, the direction and size of the impulse and the size of the deformation energy in addition to the impact configuration and the known impact velocities. If these basic parameters are in harmony, the basic goal for the reconstruction is satisfied. Modelling assisted by a simulation program allows research to move closer to the performed test. The example of the introduced frontal collision of a moving and stationary vehicle with a very small overlap and subsequent rollover is relatively specific and complicated. With a view to the vehicle's rollover caused partly by contact of the tyres, i.e. rolling up, the actual post-impact progress is fundamentally affected by the exactly determined position of the centre of gravity in the longitudinal as well as vertical direction, the turning of the wheels, friction between the body and the surface during the rollover, deceleration during the motion and the used model of tyres. A combination of the mentioned values within a technically acceptable range enables one to find the control parameters to a satisfactory extent.

\section{CONCLUSION}

The introduced crash test showed the potentials for the detection of significant values when evaluating the progress and cause of a traffic accident. It is necessary to consider the input values within a technically acceptable range because they are not exactly known from data based on real traffic accidents. Reconstructive modelling represents an inversion task where it is necessary to detect the impact configurations and initial parameters of the motion from the effects of the traffic accident.

Ing. TOMÁš COUFAL, Ph.D.

E-mail: tomas.coufal@usi.vutbr.cz

Ing. MAREK SEMELA, Ph.D.

E-mail: marek.semela@usi.vutbr.cz

Vysoké učení technické v Brně, Ústav soudního inženýrství

Purkyňova 464/118, 61200 Brno, Česká republika 


\section{ABSTRAKT}

Článek představuje kompletní výsledky čelního nárazu s malým překrytím vozidla jedoucího rychlostí cca $12 \mathrm{~m} / \mathrm{s}$ do druhého stojícího vozidla s následným převrácením jednoho $z$ vozidel. Za této situace, $k d y$ nedošlo $k$ zasažení důležitých nosných struktur, není dobře chráněna posádka vozidla. Dưraz byl kladen na stanovení a prezentaci nárazových parametrů pro aplikaci při analýze silničních nehod a případnou simulaci s podporou simulačních programů. Byla experimentálně změřená a analyzována data z nárazové zkoušky s následným převrácením vozidla. Nárazová zkouška ukázala, jak extrémně nebezpečné jsou střety s malým prekrytím pro posádku vozidla s možností převrácení vozidla poranění hlavy a krku pasažérů, a to i v připadě relativně nizké rychlosti. Vozidlo bylo řizeno fyzickou osobou řidiče, který trpěl po testu poraněním hlavy a bolestivostí krku po dobu několika dnů. Testem byla získána rovněž data pro analýzu nehody pomocí software.

\section{KLÍČOVÁ SLOVA}

nárazová zkouška; náraz; vozidlo; dopravní nehoda; soudní inženýrství; převrácení; malé překrytí;

\section{REFERENCES}

[1] Batista M. Note on Linear Force Model in Car Accident Reconstruction. ARXIV: eprint arXiv:physics/0511127 [Internet]. 2005 Nov. [cited 2014 Jan 22]; Avalaible from: http://arxiv.org/abs/physics/0511127v3.

[2] Branch RM, Branch R. Vehicle accident analysis and reconstruction methods. Warrendale: SAE International; 2011.

[3] Burg H. Moser A. Traffic Accident Reconstruction: Accident recording, driving dynamics, simulation [in German]. Wiesbaden: Vieweg Teubner, 2009;2:1032.

[4] Campbell KL. Energy Basis for Collision Severity. Warrendale: SAE International, 1974. doi: 10.4271/740565

[5] Cichos D, et al. Crash Analysis Criteria Description. Bergisch Gladbach: Workgroup Data Processing Vehicle Safety [Internet]. 2008 May [cited 2014 Feb 01]; [about 156 pp]. Avalaible from: http://www.crash-network.com/CrashAnalysisCriteria_2.1.1.pdf.

[6] Cipriani A, Bayan F, Woodhouse M, et al. Low Speed Collinear Impact Severity: A Comparison Between Full Scale Testing and Analytical Prediction Tools with Restitution Analysis. Detroit: SAE International. 2002; doi: 10.4271/2002-01-0540.

[7] Huang M. Vehicle crash mechanics. Boca Raton: CRC Press; 2002.

[8] Hugemann $W$ et al. Accident reconstruction [in German]. Münster: Autorenteam. 2007; 1:649-1254.

[9] McHenry BG. The algorithms of CRASH. Cary: McHenry Software, Inc. [Internet]. 2001 [cited 2014 Jan 28]. Avalaible from: www.mchenrysoftware.com.

[10] SAE J1733. Sign Convention for Vehicle Crash Testing. Warrendale: Society of Automotive Engineers, Inc.; 1994.

[11] Seiffert U, Wech L. Automotive safety handbook. Warrendale: SAE International; 2007.
[12] Smith R, Tsongos N. Crash Phase Accident Reconstruction. Warrendale: SAE International; 1986. doi: 10.4271/860209

[13] Strohrer ChE, Wolley RL, James MB, et al. Crush energy in accident reconstruction. Warrendale: SAE International; 1986. doi: 10.4271/860371.

[14] Eichberger A, Schimpl W, Weber Ch, Steffan H. A new crash test configuration for car-to-car frontal collisions with small lateral overlap. International Journal of Crashworthiness; 2007;12(2): 93-100. doi:10.1080/13588260701431762

[15] Sherwood CP, Mueller BC, Nolan JM, Zuby DS, Lund AK. Development of a frontal small overlap crashworthiness evaluations test. Traffic Injury Prevention. 2013;14:128-135. doi: 10.1080/15389588.2013.790539

[16] IIHS - Insurance Institute of Highway Safety - an independent, nonprofit scientific and educational organization dedicated to reducing the losses - deaths, injuries and property damage - from crashes on the nation's roads [Internet]. Avalaible from: www.iihs.org.

[17] NHTSA - National Highway Traffic Safety Administration - dedicated to achieving the highest standards of excellence in motor vehicle and highway safety [Internet]. Avalaible from: www.nhtsa.gov.

[18] Sanuders J. Parents D. Repeatability of a small overlap and an oblique moving deformable barrier test procedure. SAE International Journal of Transportation Safety. 2013; 1(2): 309-329. doi: 10.4271/2013-01-0762

[19] Kullgren A, Ydenius A, Tingvall C. Frontal impacts with small partial overlap: Real life data from crash recorders. International Journal of Crashworthiness. 1998;3(4):335-343. doi: 10.1080/15389588.2013.790539

[20] Parker D, Zolock J, Keefer R. A study of vehicle impacts during dolly rollover tests and comparison to frontal and side impact tests. SAE Technical Paper; 2014. doi: 10.4271/2014-01-0529

[21] Kim T, Kerrigan J, Bollapragada V, Crandall J, Tangirala R, Guerrero M. Rollover initiation simulations for designing rollover initiation test system. SAE Technical Paper; 2014. doi: 10.4271/2014-01-0530.

[22] Deyerl E, Cheng L, Gatti J. Two-dimensional collision simulations of low-speed crash testSAE 2013, SAE Technical Paper; 2013. doi: 10.4271/2013-01-0793.

[23] Iraeus J, Lindquist M, Wistrand S,, Sibgard E, Pipkorn B. Evaluation of chcest injury mechanisms in nearside oblique frontal impacts Annals of Advances in Automotive Medicine. Proceedings of the 57th Annual Scientific Conference of the Association for the Advancement of Automotive Medicine; 2013.

[24] Kikuchi T, Nakao T, Watanabe T, Saeki H, Okabe T. An Investigation of Injury Factors Concerning Drivers in Vehicles Involved in Small-Overlap Frontal Crashes. SAE Int. J. Passeng. Cars - Mech. Syst. 2012;5(2):801806. doi:10.4271/2012-01-0599.

[25] Semela M, Bradáč A. Procedure of collision solution with the help of Virtual CRASH software and possibilies of results validation [in Czech]. Soudní inženýrství. 2007;18(3):118-129. 